\title{
PENGARUH PERKUATAN SHEAR KEY TERHADAP ANGKA KEAMANAN DAN PENURUNAN MAKSIMUM PADA TIMBUNAN DI ATAS TANAH LUNAK
}

\author{
M. Indra Aji Kurniawan ${ }^{1}$, Bambang Setiawan ${ }^{2}$, Noegroho Djarwanti ${ }^{3}$ \\ 1)Mahasiswa Program Studi Teknik Sipil, Universitas Sebelas Maret Surakarta \\ 2),3)Dosen KBK Geoteknik, Program Studi Teknik Sipil, Universitas Sebelas Maret Surakarta \\ J1. Ir. Sutami No.36 A, Jebres, Surakarta 57126; Telp. 0271-634524 \\ Email : muhendra10@gmail.com
}

\begin{abstract}
Embankments that are located above soft soil can cause problems such as the big settlement that occurs which give impact on the low safety factor of embankments. One of the solutions to overcome this problem is by using a shear key. This study divides it into 2 types of installations, those are to the outward direction and into the inside direction of embankment with the slope slide 1:2. Model variations which are used with dimensions of depth $2 \mathrm{~m}, 3 \mathrm{~m}, 4 \mathrm{~m}, 5 \mathrm{~m}$ and bottom width $1 \mathrm{~m}, 2 \mathrm{~m}$ and $3 \mathrm{~m}$. The purpose of this study was to determine the effect of using a shear key in terms of safety factor and maximum settlement with the help of finite element method (FEM). The result showed that the value of the maximum safety factor that occurred in the outside direction was 1,419 where it increase $11.88 \%$, while the maximum settlement that occurred reached $0.353 \mathrm{~m}$. The maximum safety factor of the inside direction installation was 1.313 with the increased percentage 3.54\%, where the maximum settlement that occurred was $0.409 \mathrm{~m}$. The outward direction of shear key installation become the most effective strengthening installation with optimum dimensions variations in depth $4 \mathrm{~m}$ and bottom width $3 \mathrm{~m}$. Shear key strengthening can be an alternative way to increase the stability of the embankment above soft soil.
\end{abstract}

Keywords: soft soil, SF, shear key

\begin{abstract}
Abstrak
Timbunan yang terletak di atas tanah lunak dapat menimbulkan permasalahan yaitu nilai penurunan yang terjadi sangat besar sehingga berdampak pada rendahnya nilai angka keamanan timbunan. Salah satu solusi untuk mengatasi permasalahan tersebut yaitu dengan menggunakan perkuatan shear key. Penelitian ini membagi kedalam 2 tipe pemasangan, yaitu arah luar dan dalam timbunan dengan kemiringan lereng timbunan 1:2. Variasi model yang digunakan dengan dimensi kedalaman $(H)$ $2 \mathrm{~m}, 3 \mathrm{~m}, 4 \mathrm{~m}, 5 \mathrm{~m}$ dan lebar bawah $(L) 1 \mathrm{~m}, 2 \mathrm{~m}$ dan $3 \mathrm{~m}$. Tujuan dari penelitian ini adalah untuk mengetahui pengaruh penggunaan shear key yang ditinjau dari angka keamanan dan penurunan maksimum dengan bantuan metode elemen hinga $(\mathrm{MEH})$. Hasil pemograman didapatkan bahwa nilai angka keamanan maksimum yang terjadi pada arah luar sebesar 1,419 dimana mengalami kenaikkan 11,88\% sedangkan penurunan maksimum yang terjadi mencapai 0,353 m. Angka keamanan maksimum pada pemasangan arah dalam sebesar 1,313 dengan prosentase kenaikkan 3,54\%, dimana penurunan maksimum yang terjadi sebesar $0,409 \mathrm{~m}$. Pemasangan arah luar timbunan menjadi pemasangan perkuatan paling efektif dengan dimensi optimum terdapat pada variasi $(H) 4 \mathrm{~m}$ dan $(L) 3 \mathrm{~m}$. Perkuatan shear key dapat menjadi salah satu alternatif cara untuk meningkatkan stabilitas timbunan di atas tanah lunak.
\end{abstract}

Kata kunci : tanah lunak, SF, shear key

\section{PENDAHULUAN}

Pembangunan jalan yang terus mengalami peningkatan dari tahun ke tahun selalu berdampak pada kebutuhan lahan yang semakin meningkat. Kebutuhan lahan yang semakin meningkat mengakibatkan pembangunan konstruksi jalan berupa timbunan dilaksanakan pada daerah atau lahan dengan kondisi tanah dasar yang bermasalah (lunak). Kondisi tanah dasar lunak memiliki daya dukung yang rendah dan akan mengakibatkan kegagalan konstruksi jika dibangun bangunan sipil di atasnya. Permasalahan yang sering kali terjadi pada timbunan yang dibangun di atas tanah lunak yaitu penurunan yang terjadi sangat besar dan berdampak pada tingkat keamanan suatu konstuksi jalan tersebut. Tingkat keamanan suatu konstruksi jalan berupa timbunan yang dibangun di atas tanah lunak dipengaruhi oleh beberapa faktor, diantaranya adalah tinggi timbunan, kemiringan dan beban yang bekerja di atasnya. Kondisi lereng timbunan dengan kemiringan, tinggi timbunan dan beban yang besar akan mengakibatkan kelongsoran (slip) pada timbunan.

Upaya yang digunakan untuk mengatasi permasalahan tersebut yaitu dengan menggunakan perkuatan berupa pemasangan shear key pada kaki timbunan. Shear key merupakan sistem pengunci pada timbunan ataupun penghalang dari longsoran karena akibat beban yang berlebih di atas tanah lunak. Fungsi dari perkuatan shear key antara lain : meningkatkan stabilitas timbunan, meningkatkan kuat geser tanah, meningkatkan angka keamanan timbunan. 


\section{LANDASAN TEORI}

\section{Tanah Lunak}

Tanah lunak merupakan tanah yang memiliki kuat geser rendah, kadar air tinggi, nilai daya dukung rendah, kompressibilitas yang besar dan permeabilitas rendah, kondisi demikian mengakibatkan proses konsolidasi berlangsung dalam jangka waktu yang sangat lama. Toha (1989) mengatakan bahwa tanah lunak memiliki kadar air 80\% hingga 100\%, butiran tanah lolos saringan no. 200 yaitu lebih besar dari $90 \%$, selain itu memiliki kuat geser $20 \mathrm{kN} / \mathrm{m}^{2}$ hingga $40 \mathrm{kN} / \mathrm{m}^{2}$ dimana nilai liquid limit (LL) sebesar 80\% hingga 110\% dan plastis limit (PL) sebesar 30\% hingga $45 \%$.

\section{Shear Key}

Shear key merupakan pengunci dasar timbunan tanah pada jalan yang berguna untuk menahan longsoran (sliding) arah horizontal dan meningkatkan stabilitas lereng timbunan dengan meningkatkan resistensi di sepanjang permukaan yang berpotensi gagal (Caltrans Geotechnical Manual, December 2014). Shear key dapat meningkatkan nilai keamanan global suatu timbunan tanah dan menaikkan kuat geser tanah. Bentuk pemasangan shear key yang sering dijumpai di lapangan yaitu berbentuk persegi dan trapesium. Shear key terbentuk dari suatu material tanah granuler yang memiliki berat jenis yang tinggi sebagai contoh batu-batuan, sirtu, rockefill, limestone.

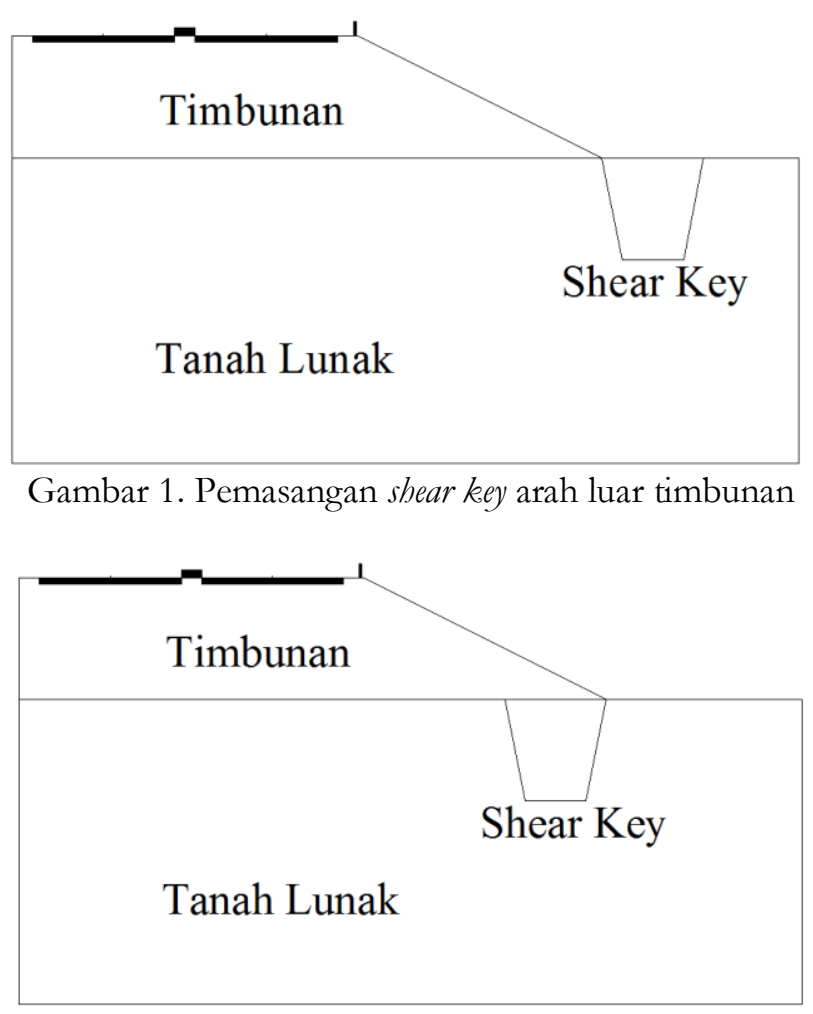

Gambar 2. Pemasangan shear key arah dalam timbunan

\section{Metode Elemen Hingga (MEH)}

Metode elemen hingga atau finite element method (FEM) adalah metode pendekatan solusi analisis struktur secara numerik dimana struktur kontinum dengan derajat kebebasan tak berhingga disederhanakan dengan diskritisasi kontinum ke dalam elemen-elemen kecil yang umumnya memiliki geometri lebih sederhana dengan kebebasan tertentu (berhingga) sehingga lebih mudah dianalisis. Metode elemen hingga merupakan salah satu metode penyelesaian pendekatan (hampiran), contohnya dengan program Plaxis. Metode ini dapat menganalisis secara simultan tegangan dan regangan yang terjadi pada tanah, maupun dapat mengubah dari derajat tak terhingga menjadi kedalam sebuah bentuk derajat yang lebih kecil (Fahriani, 2016).

\section{Konsolidasi dan displacement pada tanah lunak}

Konsolidasi adalah proses pemampatan tanah dan berkurangnya volume air dari dalam tanah akibat pemberian beban di atasnya. Hal ini dapat mengakibatkan bertambahnya daya dukung tanah, namun proses ini berlangsung sangat lama dan tidak diperbolehkan adanya bangunan yang berdiri di atasnya selama proses konsolidasi 
berlangsung. Apabila suatu lapisan tanah mengalami pembebanan di atasnya maka tanah di bawah beban yang bekerja tersebut akan mengalami kenaikkan tegangan yang berakibat terhadap penurunan tanah (settlement). Nilai penurunan primer suatu lapisan tanah menggunakan persamaan turunan konsolidasi Terzaghi pada persamaan [1] berikut ini.

$$
S c=C c \frac{H o}{1+e_{\mathrm{o}}} \log \frac{\sigma_{\mathrm{o}}+\Delta \sigma}{\sigma_{\mathrm{o}}} \mathrm{cHo} / 1+\mathrm{e}_{\mathrm{o}} \log \sigma_{\mathrm{o}}+\Delta \sigma / \sigma_{\mathrm{o}}
$$

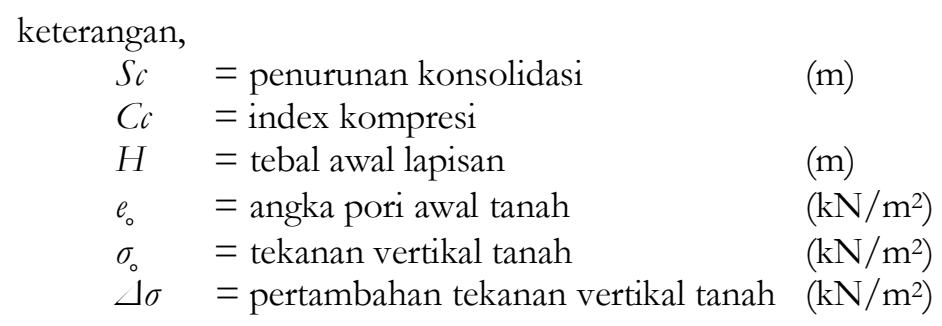

\section{Teori Mohr - Coloumb}

Timbunan mempunyai kemungkinan untuk runtuh didasari oleh tegangan geser yang terjadi pada tanah. Teori Mohr-Coulomb menunjukkan bahwa tegangan geser yang mendasari keruntuhan dapat berasal dari beban gravitasi maupun gaya lain, selain itu menurut Mohr - Coloumb bahwa keruntuhan terjadi akibat kombinasi kritis antara tegangan normal dan geser bukan hanya akibat tegangan normal dan geser dalam kondisi maksimum saja. Kriteria Mohr-Coloumb didefinisikan pada persamaan [2] berikut ini.

$$
\tau=c+\sigma \tan \phi
$$

\begin{tabular}{|c|c|c|}
\hline$\tau$ & $=$ tegangan geser & $\left(\mathrm{kN} / \mathrm{m}^{2}\right)$ \\
\hline$c$ & $=$ kohesi & $\left(\mathrm{kN} / \mathrm{m}^{2}\right)$ \\
\hline$\sigma$ & $=$ tegangan normal & $\left(\mathrm{kN} / \mathrm{m}^{2}\right)$ \\
\hline$\varphi$ & $=$ sudut geser dalam & $(\mathrm{o})$ \\
\hline
\end{tabular}

keterangan,

\section{Analisa stabilitas global timbunan}

Stabilitas timbunan sangat dipengaruhi oleh beberapa faktor, antara lain terdapat dua faktor yang mempengaruhi kelongsoran timbunan yaitu faktor internal dan faktor eksternal. Faktor internal merupakan faktor yang berasal dari dalam yang meliputi gaya geser, tekanan tanah lateral dll, sedangkan Faktor eksternal dapat berupa beban kendaraan, beban angin dan gempa. Metode elemen hingga dapat menerapkan teknik kekuatan geser reduksi. Perhitungan faktor keamanan dengan metode elemen hingga untuk analisis stabilitas menggunakan prosedur $p h i-c$ reduction. Dengan cara tersebut parameter kuat geser berupa sudut geser dan kohesi tanah dikurangi secara menerus sehingga keruntuhan pada struktur terjadi. Faktor keamanan global dalam perhitungan metode elemen hingga ditunjukkan pada persamaan [3] berikut ini.

$$
\Sigma M_{S f}=\frac{C_{\text {input }}}{C_{\text {reduced }}}=\frac{\tan \varphi_{\text {input }}}{\tan \varphi_{\text {reduced }}}
$$

\begin{tabular}{|c|c|c|}
\hline$\Sigma M_{s f}$ & $=$ angka keamanan & \\
\hline Cinput & $=$ kohesi & $\left(\mathrm{kN} / \mathrm{m}^{2}\right)$ \\
\hline$c_{\text {reduced }}$ & $=$ kohesi tereduksi & $\left(\mathrm{kN} / \mathrm{m}^{2}\right)$ \\
\hline$\varphi_{\text {input }}$ & $=$ sudut geser dalam & $\left({ }^{\circ}\right)$ \\
\hline$\varphi_{\text {reduced }}$ & $=$ sudut geser tereduksi & $(\mathrm{o})$ \\
\hline
\end{tabular}

keterangan,

\section{METODE}

Pengujian yang dilakukan dalam penelitian ini meliputi perbandingan antara perkuatan timbunan di atas tanah lunak dengan menggunakan shear key dan timbunan yang tidak menggunakan perkuatan shear key pada kemiringan lereng timbunan 1:2 untuk menentukan nilai angka keamanan dan penurunan maksimum yang terjadi. Model analisis perhitungan yang dilakukan adalah dengan menggunakan metode elemen hingga (MEH). Pemodelan elemen hingga yang dipilih dengan menggunakan plane strain. Pemodelan material tanah yang dipilih berupa Mohr- 
Coloumb. Perhitungan (calculation type) untuk penurunan maksimum menggunakan consolidation analysis dan untuk mengetahui nilai angka keamanan global timbunan digunakan phi/c reduction. Pemodelan dilakukan dengan variasi pada lebar bawah (L) 1m, 2m, 3m maupun pada kedalaman shear key $(H)$ mulai dari $2 \mathrm{~m}$, 3m, $4 \mathrm{~m}$, dan $5 \mathrm{~m}$ yang digunakan pada perkuatan timbunan jalan di atas tanah lunak. Pemodelan dilakukan dengan 2 tahapan, tahap pertama melakukan percobaan untuk kondisi tanah awal yaitu timbunan tanpa adanya perkuatan. Tahap kedua, melakukan pengujian untuk timbunan dengan menggunakan perkuatan shear key.

\section{Parameter Input}

Parameter input data tanah yang digunakan dalam metode elemen hingga (finite elemen method, FEM) berupa pendekatan perilaku tanah dengan model Mohr-Coulomb. Model Mohr-Coulomb ini terdiri dari lima buah parameter tanah, antara lain : modulus Young $(E)$, angka poison $(\nu)$, sudut gesek $(\varphi)$, kohesi $(c)$, dan sudut dilatansi $(\psi)$. Parameter-parameter data tanah dan shear key yang digunakan dalam penelitian ini ditunjukkan pada Tabel 1 berikut ini.

Tabel 1. Parameter data tanah dan shear key

\begin{tabular}{lcccc}
\hline \multicolumn{1}{c}{ Properties } & Tanah Asli & Tanah Timbunan & Shear Key & Unit \\
\hline Model & Mohr-Coloumb & Mohr-Coloumb & Mohr Coloumb & - \\
\hline Type & Drained & Drained & Drained & - \\
\hline$\gamma_{\text {unsat }}$ & 10,19 & 12,06 & 23,90 & $\mathrm{kN} / \mathrm{m}^{3}$ \\
\hline$\gamma_{\text {sat }}$ & 16,08 & 17,26 & 24,10 & $\mathrm{kN} / \mathrm{m}^{3}$ \\
\hline$k_{x}$ & 0,042 & 0,007 & 2 & $\mathrm{~m} / \mathrm{day}$ \\
\hline$k_{y}$ & 0,042 & 0,007 & 2 & $\mathrm{~m} / \mathrm{day}$ \\
\hline$E_{r e f}$ & 3922,66 & 73549,87 & 26000 & $\mathrm{kN} / \mathrm{m}^{3}$ \\
\hline$v$ & 0,40 & 0,30 & 0,33 & - \\
\hline$c_{r e f}$ & 11,77 & 3,92 & 0 & $\mathrm{kN} / \mathrm{m}^{2}$ \\
\hline$\varphi$ & 4 & 28 & 43 & $\circ$ \\
\hline$\psi$ & - & - & - & $\circ$ \\
\hline
\end{tabular}

\section{Klasifikasi Tanah Asli dan Timbunan Berdasarkan Metode AASHTO}

Identifikasi dilakukan dengan membandingkan parameter data tanah timbunan yang digunakan sebagai tanah existing maupun subgrade jalan dengan cara pengklasifikasian tanah berdasarkan metode AASHTO (American Association of State Highway and Transportation Officials Classification). Data tanah yang dibutuhkan untuk identifikasi tanah berdasarkan metode AASHTO antara lain berupa nilai liquid limit (LL), plastis limit (PL), plasticity index (PI), persen lolos saringan No.200 (A) dan nilai GI.

Tabel 2. Hasil klasifikasi tanah asli dan timbunan berdasarkan metode AASHTO

\begin{tabular}{cccc}
\hline Parameter Tanah & Unit & Tanah Asli (Existing) & Tanah Timbunan (Subgrade) \\
\hline A & $\%$ & 89,31 & 13,01 \\
\hline Persen lolos saringan No. 200) & $\%$ & 68 & 46 \\
\hline$P L$ & $\%$ & 32 & 27 \\
\hline$P I$ & $\%$ & 36 & $-0,1791$ \\
\hline GI dari perhitungan & 37,79 & 0 \\
\hline GI yang digunakan & 20 & A-2-7
\end{tabular}

\section{Beban Kendaraan}

Beban kendaraan yang digunakan pada penelitian ini berdasarkan Rancangan Standar Nasional Indonesia tahun 2014 (RSNI T-14-2004) dan Binamarga tahun 1987 menyatakan bahwa muatan sumbu terberat (MST) yang diijinkan untuk jalan arteri kelas IA adalah sebesar 10 ton. Di dalam analisis struktur perkerasan ditentukan MST besarnya adalah 10 ton sebagai beban statis. Besarnya MST 10 ton ditambah dengan beban overload sebesar 20\% menjadi 12 ton pada as kendaraan. Sehingga apabila didistribusikan kedalam as setiap roda kendaraan menerima beban sebesar 6 ton atau setara dengan $60 \mathrm{kN} / \mathrm{m}$ (lihat Gambar 3). 


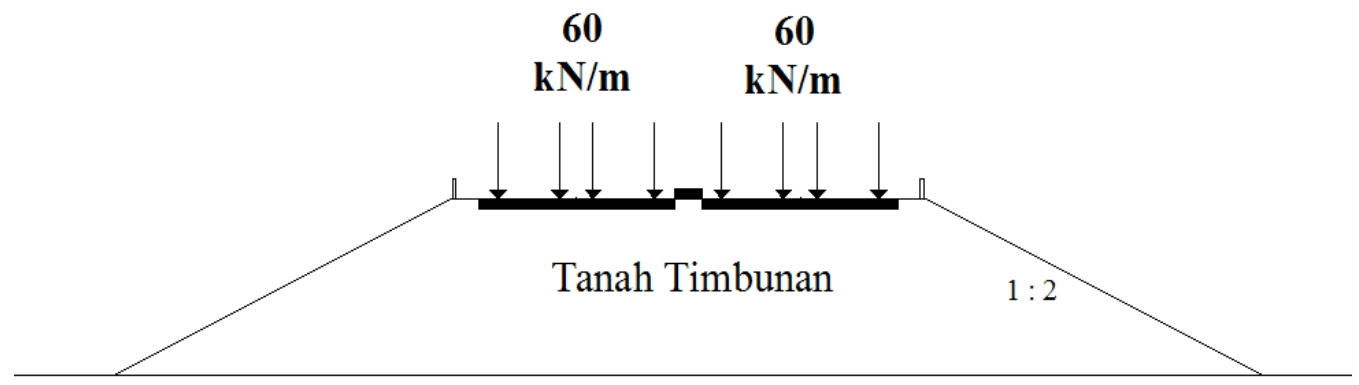

Gambar 3. Pembebanan pada 4 lajur penuh

\section{HASIL DAN PEMBAHASAN}

\section{Analisis Dengan Metode Elemen Hingga}

Langkah awal dalam melakukan pemodelan dengan menggunakan metode elemen hingga yaitu dengan membuat bentuk geometri timbunan jalan. Model tanah asli dibuat dengan dimensi lebar $80 \mathrm{~m}$ dan kedalaman $25 \mathrm{~m}$ dari muka tanah dasar. Model timbunan yang digunakan berbentuk trapesium dimana dimensi lebar atas timbunan 17 $\mathrm{m}$, lebar bawah timbunan $31 \mathrm{~m}$ dan ketinggian timbunan $3 \mathrm{~m}$. Kondisi muka air tanah diasumsikan berada di bawah kedalaman $-25 \mathrm{~m}$ dari muka tanah dasar (lihat Gambar 4). Perhitungan hasil yang diperoleh pada penelitian ini berupa angka keamanan $(S F)$ dan deformasi (penurunan maksimum) yang didapat dari pengamatan secara visual melalui hasil pemograman dengan bantuan metode elemen hingga (lihat Gambar 5a dan Gambar $5 b)$.

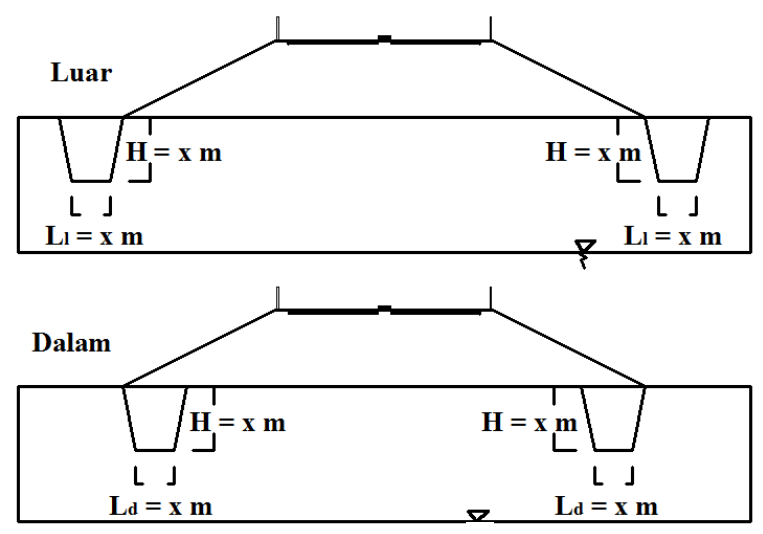

Gambar 4. Pemodelan geometri timbunan dengan perkuatan shear key

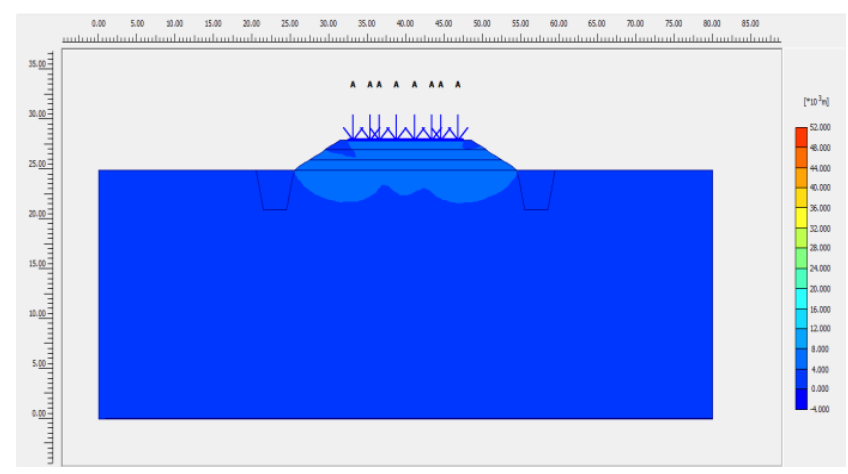

a)

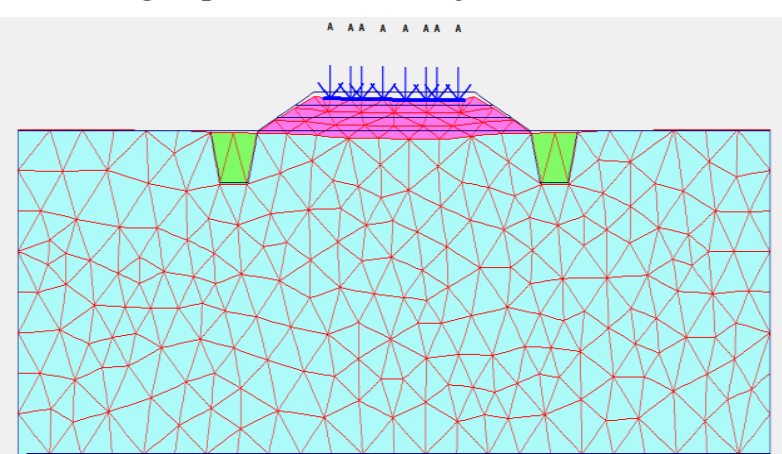

b)

Gambar 5. Output program a). angka keamanan $(S F)$

b). deformasi (penurunan maksimum) 
Grafik hubungan angka keamanan dengan kedalaman shear key ditunjukkan pada Gambar 6. Gambar 6 tersebut menunjukkan bahwa perkuatan shear key dengan dimensi lebar $L_{l}=3 \mathrm{~m}$ memiliki nilai angka keamanan terbesar dibandingkan dengan dimensi $L_{l}=2 \mathrm{~m}$ dan $L_{l}=1 \mathrm{~m}$. Nilai angka keamanan $(S F)$ yang diperoleh untuk timbunan tanpa menggunakan perkuatan shear key adalah 1,268, dimana jauh tidak memenuhi terhadap batas nilai angka keamanan minimum yaitu 1,4. Setelah adanya penambahan perkuatan shear key pada tanah yang ada, nilai angka keamanan yang diperoleh semakin meningkat mendekati nilai angka minimum. Nilai angka keamanan yang ditunjukkan pada Gambar 6. terlihat bahwa variasi dimensi shear key dengan hasil nilai angka keamanan yang melebihi batas minimum terdapat pada kedalaman $3 \mathrm{~m}$ hingga $5 \mathrm{~m}$ dan lebar sebesar $3 \mathrm{~m}$. Nilai keamanan maksimum yang terjadi pada perkuatan luar timbunan sebesar 1,419 dengan prosentase kenaikkan 11,88\% terhadap tanpa perkuatan. Gambar 6. di bawah ini merupakan perbandingan untuk menentukan nilai optimum dengan memperhatikan angka keamanan dari variasi dimensi shear key yang diperoleh akibat adanya beban perkuatan dan timbunan di atas tanah lunak. Nilai optimum didapat pada dimensi shear key dengan $H=4 \mathrm{~m}$ dan $L_{l}=3 \mathrm{~m}$. Hasil nilai angka keamanan pada perkuatan luar timbunan dengan kemiringan lereng 1:2 dapat dilihat pada Gambar 6 berikut ini.

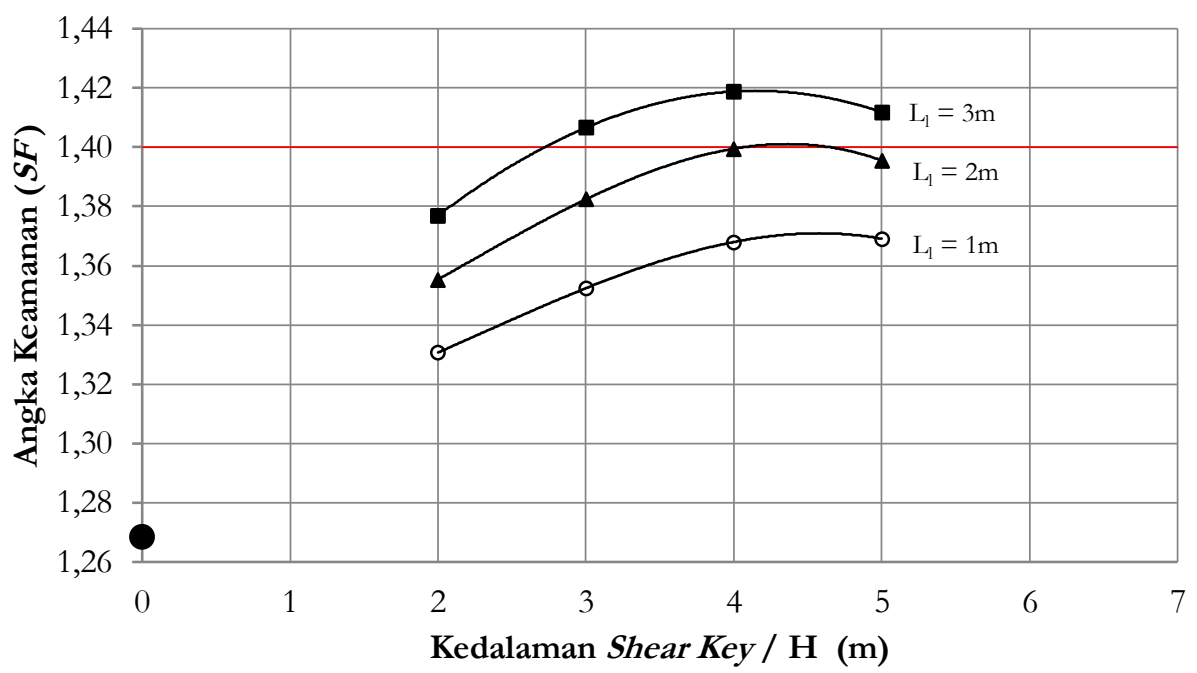

Gambar 6. Hasil angka keamanan $(S F)$ pada perkuatan luar timbunan

Angka keamanan terhadap perkuatan dalam dengan kemiringan lereng timbunan 1:2 menunjukkan bahwa untuk dimensi shear key dengan kedalaman $2 \mathrm{~m}$ hingga $5 \mathrm{~m}$ dan lebar $1 \mathrm{~m}$ sampai $3 \mathrm{~m}$, memperlihatkan hasil nilai angka keamanan tidak mencapai batas minimum. Nilai angka keamanan $(S F)$ yang diperoleh untuk timbunan tanpa menggunakan perkuatan adalah 1,268 , setelah adanya penambahan perkuatan kenaikkan nilai angka keamanan yang terjadi tidak melebihi batas minimum. Perkuatan arah dalam timbunan memberikan penambahan terhadap nilai angka keamanan yang jauh lebih kecil daripada perkuatan arah luar timbunan. Perkuatan shear key dengan dimensi lebar $L_{d}=1 \mathrm{~m}$ memiliki nilai angka keamanan terbesar dibandingkan dengan dimensi $L_{d}=2 \mathrm{~m}$ dan $L_{d}=$ $1 \mathrm{~m}$, dimana nilai angka keamanan terbesar pada perkuatan dalam sebesar 1,313 dengan prosentase kenaikkan 3,54\% terhadap tanpa perkuatan. Hasil nilai keamanan pada perkuatan dalam dengan kemiringan lereng 1:2 ditunjukkan pada Gambar 7. berikut ini.

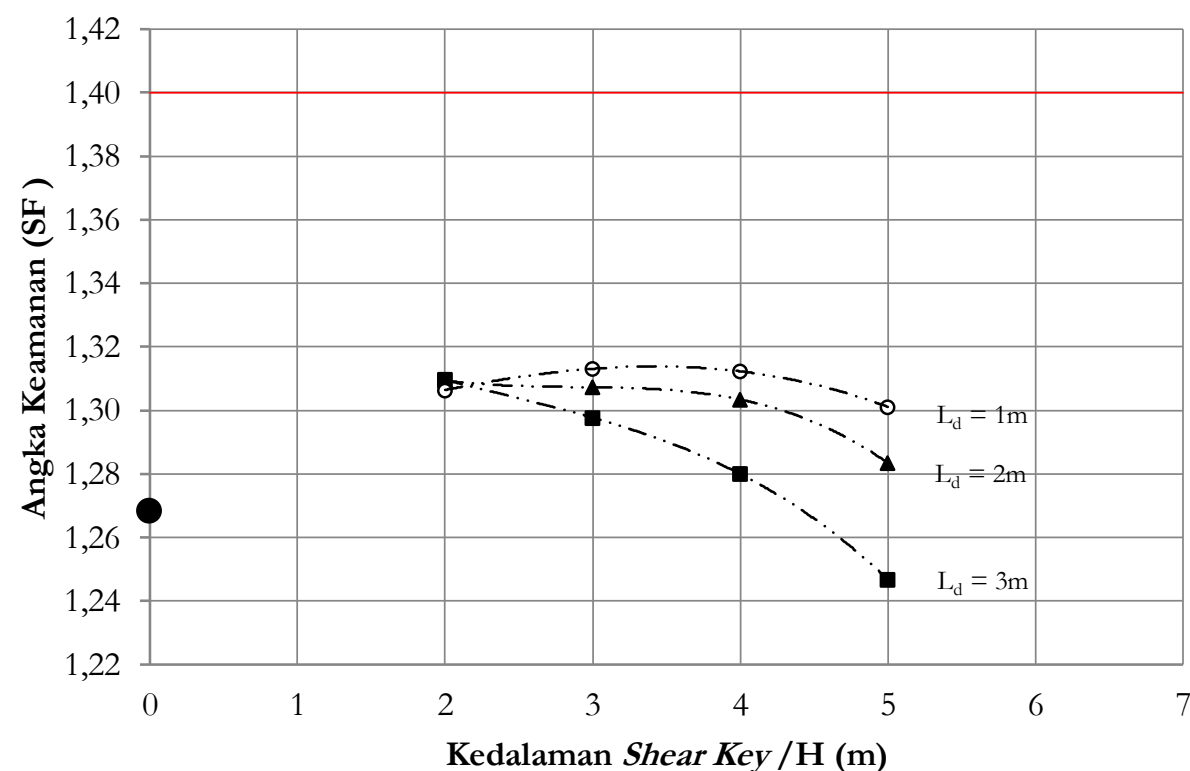


Gambar 7. Hasil angka keamanan $(S F)$ pada perkuatan dalam timbunan

\section{Penurunan Maksimum}

Hasil yang diperoleh dari analisis dengan menggunakan metode elemen hingga (MEH) selain angka keamanan juga berupa penurunan maksimum tanah asli yang berupa tanah lunak. Penurunan maksimum yang dimaksud pada penelitian adalah penurunan total yang terjadi akibat adanya beban timbunan dan beban perkuatan pada tanah lunak. Hasil penurunan maksimum tanpa adanya perkuatan sebesar $0,332 \mathrm{~m}$, setelah adanya penambahan perkuatan luar timbunan berupa shear key dapat dilihat pada Gambar 8. berikut ini.

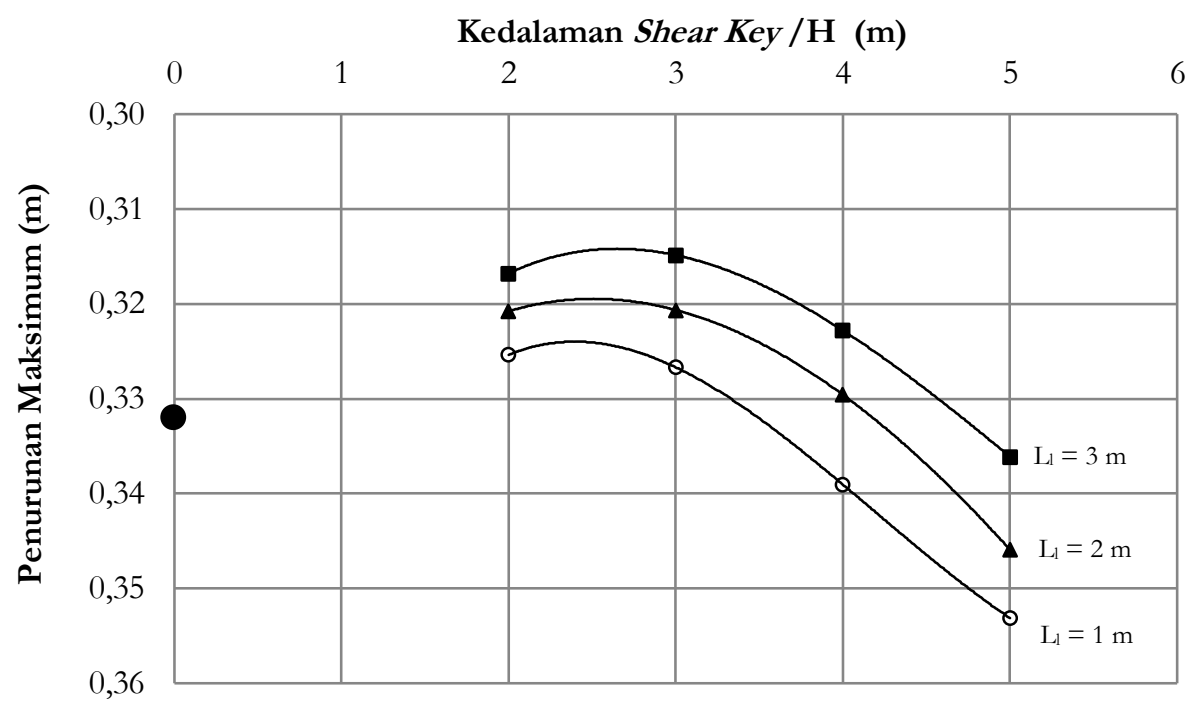

Gambar 8. Penurunan maksimum pada perkuatan luar timbunan

Gambar 8. di atas menunjukkan bahwa pada variasi dimensi shear key dengan lebar $1 \mathrm{~m}$ memberikan penurunan yang lebih besar daripada lebar $2 \mathrm{~m}$ dan $3 \mathrm{~m}$. Hal ini menunjukkan semakin besar dimensi kedalaman dan semakin kecil lebar perkuatan mengakibatkan penurunan menjadi semakin besar. Penurunan terbesar pada perkuatan luar timbunan terdapat pada dimensi shear key dengan kedalaman $5 \mathrm{~m}$ dan lebar $1 \mathrm{~m}$ sebesar $0,353 \mathrm{~m}$, dengan prosentase kenaikkan penurunan terhadap tanpa perkuatan $6,36 \%$.

Penurunan maksimum terhadap perkuatan arah dalam memberikan hasil yang berbeda dengan perkuatan arah luar timbunan. Penurunan maksimum arah dalam lebih besar daripada arah luar timbunan. Hal ini terjadi karena pada perkuatan arah dalam timbunan, perkuatan shear key juga menerima beban secara langsung dari beban timbunan, beban rigid pavement, dan beban kendaraan yang berada di atas perkuatan, sehingga penurunan bertambah besar daripada perkuatan ke arah luar timbunan. Penurunan terbesar terdapat pada perkuatan shear key dengan lebar $3 \mathrm{~m}$ dan kedalaman $5 \mathrm{~m}$ yaitu $0,409 \mathrm{~m}$. Prosentase kenaikkan penurunan maksimum pada variasi dimensi lebar $3 \mathrm{~m}$ dan kedalaman $5 \mathrm{~m}$ sebesar $23,11 \%$. Hasil penurunan maksimum perkuatan arah dalam timbunan dengan kemiringn lereng 1:2 dapat dilihat pada Gambar 9. berikut ini.

Kedalaman Shear Key /H (m)

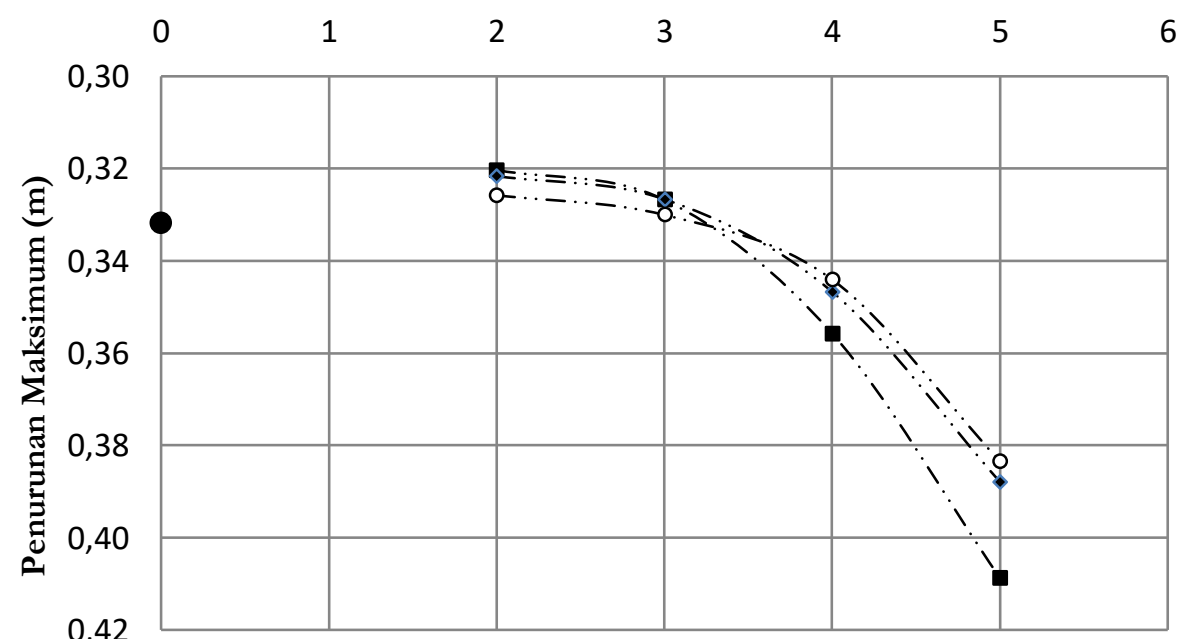




$$
\begin{aligned}
\mathrm{Ld}_{\mathrm{d}} & =1 \mathrm{~m} \\
\mathrm{~L}_{\mathrm{d}} & =2 \mathrm{~m} \\
\mathrm{Ld}_{\mathrm{d}} & =3 \mathrm{~m}
\end{aligned}
$$

Gambar 9. Penurunan maksimum pada perkuatan dalam timbunan

Hasil rekapitulasi analisis stabilitas global timbunan dengan kemiringan lereng timbunan 1:2 pada jalan di atas tanak lunak dengan perkuatan shear key disajikan pada Tabel 4 berikut ini.

Tabel 4. Hasil rekapitulasi analisis stabilitas global timbunan dengan perkuatan shear key

\begin{tabular}{ccccccc}
\hline Variasi & \multicolumn{2}{c}{ Dimensi } & \multicolumn{2}{c}{ Arah Luar } & \multicolumn{2}{c}{ Arah Dalam } \\
& $H$ & $L$ & $S F$ & $\delta y$ & $S F$ & $\delta y$ \\
\hline \multirow{3}{*}{ Variasi 1 } & 0 & 0 & 1.268 & 0.332 & 1.268 & 0.332 \\
& 2 & 1 & 1.331 & 0.325 & 1.306 & 0.326 \\
& 3 & 1 & 1.352 & 0.327 & 1.313 & 0.330 \\
& 4 & 1 & 1.368 & 0.339 & 1.312 & 0.344 \\
& 5 & 1 & 1.369 & 0.353 & 1.301 & 0.383 \\
Variasi 2 & 0 & 0 & 1.268 & 0.332 & 1.268 & 0.332 \\
& 2 & 2 & 1.355 & 0.321 & 1.309 & 0.322 \\
& 3 & 2 & 1.382 & 0.321 & 1.307 & 0.327 \\
& 4 & 2 & 1.399 & 0.330 & 1.303 & 0.347 \\
& 5 & 2 & 1.396 & 0.346 & 1.283 & 0.388 \\
& 0 & 0 & 1.268 & 0.332 & 1.268 & 0.332 \\
& 2 & 3 & 1.377 & 0.317 & 1.309 & 0.320 \\
& 3 & 3 & 1.407 & 0.315 & 1.298 & 0.327 \\
& 3 & 3 & 1.419 & 0.322 & 1.280 & 0.356 \\
& 4 & 3 & 1.412 & 0.336 & 1.247 & 0.408 \\
\hline
\end{tabular}

\section{SIMPULAN}

Penggunaan perkuatan shear key dapat meningkatkan nilai angka keamanan yang terjadi dari 1,268 menjadi 1,419 untuk perkuatan luar, sedangkan untuk perkuatan dalam timbunan sebesar 1,313 namun untuk perkuatan dalam timbunan belum mencapai batas minimum yang diberikan oleh PU Pd T-11-2005-d tentang batas minimum angka keamanan untuk timbunan jalan. Kenaikkan nilai angka keamanan pada arah luar timbunan lebih besar yaitu $11,88 \%$ dibandingkan arah dalam timbunan yaitu sebesar 3,54\%. Perkuatan arah luar timbunan lebih memberikan pengaruh signifikasi nilai angka keamanan daripada perkuatan arah dalam timbunan.

Penurunan maksimum pada arah luar timbunan yaitu sebesar $0,353 \mathrm{~m}$, sedangkan pada arah dalam timbunan penurunan maksimum yang terjadi sebesar $0,409 \mathrm{~m}$. Kondisi penurunan maksimum pada perkuatan arah dalam timbunan semakin besar dimensi shear key semakin besar pula penurunan maksimum yang terjadi. Pemasangan pada arah luar timbunan memberikan pengaruh yang lebih besar daripada arah dalam timbunan. Berdasarkan hasil di atas dimensi shear key yang paling optimum terdapat pada variasi dimensi kedalaman $(H) 4 \mathrm{~m}$ dan lebar bawah $(L) 3 \mathrm{~m}$ untuk perkuatan arah luar timbunan dengan jenis tanah lunak dan material berupa rockfill.

\section{UCAPAN TERIMAKASIH}

Ucapan terimakasih kepada seluruh pihak yang telah membantu dalam penulisan artikel ini, dan juga kepada teman-teman peminatan geoteknik yang telah memberikan motivasi semangat dan bantuan berupa ilmu untuk menambah wawasan berkaitan dengan artikel ini. Tak lupa juga kepada dosen pembimbing yang telah membimbing peneliti dalam menyelesaikan artikel ini.

\section{REFERENSI}


Aminjavaheri and Karami. (2014). Application of Shear Keys to Improve the Slope Stability of Earth Dams on Weak Allwial Foundations. Iran: Department of Civil and Environmental Engineering Amirkabir University of Technology.

Caicedo., B, (2018). Geotechnics of Roads: Fundamentals, Colombia: CRC Press

Caltrans Geotechnical Manual. 2014. Departement of Transportation.

Das, B. M., (1985). Mekanika Tanah (Prinsip-Prinsip Rekayasa Geoteknis) Jilid I,2, Erlangga, Jakarta.

Hardiyatmo, H., C., (2012). Mekanika Tanah 1,2. Yogyakarta: Gadjah Mada University Press.

Pedoman Konstruksi dan Bangunan, Departemen Pekerjaan Umum No. 003/BM/2009. Jakarta Selatan.

Singh., dkk. (2018). Numerical Analysis of Effect of Berms, Shear Key and Geotextiles on Embankment Over Soft Soil. Dhanbad: Technology in Civil Engineering IIT (ISM).

Testana Engineering, INC. (2016). Laporan akhir penyelidikan tanah Kota Sidoarjo. Surabaya. 